\title{
Nutritional evaluation of differently processed cassava-soya blends in the diets of broiler chickens
}

${ }^{1}$ Amos, A. T., ${ }^{1}$ Kareem, D. U., ${ }^{2}$ Amos, A. O. and ${ }^{1}$ Idowu, O. M. O.

${ }^{I}$ Department of Animal Nutrition, College of Animal Science and Livestock Production, Federal University of Agriculture, P.M.B. 2240, Abeokuta, Ogun State, Nigeria.

${ }^{2}$ Department of Agricultural Technology, Federal College of Forestry, P.M.B. 5087, Jericho, Ibadan, Oyo State, Nigeria.

*Corresponding author: kareemdu@funaab.edu.ng

\section{Abstract}

A 56-day study was conducted to evaluate the nutritional value of differently processed cassava-soya blends (CSB) in the diets of broiler chickens. 360 day-old Cobb-500 broiler chicks used for this study were assigned to the 12 dietary treatment groups which were replicated three times with ten birds each. Two differently dried blends of cassava pulp and soybeans (dry and wet heated), mixed at four (4) different ratios were subjected to two types of dehydration methods to obtain 12 types of blends. These blends were subsequently included in the diets of broiler chickens at $15 \%$ in a $2 \times 2 \times 3$ factorial arrangement to obtain 12 dietary treatments. Eight weeks of feeding trials (starter and finisher phases) were observed. The blends were chemically analysed to determine their proximate, hydrocyanide (HCN) and trypsin inhibition unit (TIU) compositions. Growth parameters (Initial weight, final weight, weight gain, feed intake and feed conversion ratio) of the birds at both phases were also measured. Results showed that fried blend cassava and wet heated soybeans at 50:50 mixing ratio had the highest crude protein (37.72\%) and metabolizable energy (3,314 kcal/kg) with low HCN residue of $1.70 \mathrm{mg} / \mathrm{kg}$. At the starter phase, birds fed diets containing 50:50 mixing ratio of CSB had the highest final weights $(904.00 \mathrm{~g} / \mathrm{b})$ and weight gain $(31.08 \mathrm{~g} / \mathrm{b} /$ day) while those fed diets containing 80:20 mixing ratio of CSB were least $(839.00 \mathrm{~g} / \mathrm{b}$ and $29.62 \mathrm{~g} / \mathrm{h} /$ day respectively). Highest $(p<0.05)$ body weight gain per bird per day $(43.95 \mathrm{~g} / \mathrm{b} / \mathrm{d})$ and lowest feed conversion ratio (2.56) were recorded with birds fed fried blend of dry heated soybean and cassava pulp at 50:50 mixing ratio at the finisher phase. Lowest feed intake was recorded with birds fed fried blend of dry heated soybean and cassava pulp at 80:20 mixing ratio. It can be concluded that replacing 15\% inclusion fried CSB blend of dry heated raw soya beans mixed with cassava at 50:50 of CSB blends in diets of broiler chickens resulted in higher weight gain at both starter and finisher phase, while dehydration by sun drying and 50:50 mixing ratio improved the feed conversion ratio of the birds at finisher phase.

Keywords: Broiler chicken, cassava-soya blend, growth performance, hydrocyanide, trypsin

\section{L'Évaluation nutritionnelle des mélanges manioc-soja transformés différemment dans l'alimentation des poulets a griller}

\section{Résumé}

Une étude de 56 jours a été menée afin d'évaluer la valeur nutritive des mélanges maniocsoja (CSB) transformés différemment dans les régimes alimentaires des poulets à griller. Les poussins 'cobb-500' de 360 jours utilisés pour cette étude ont été assignés aux 12 groupes de traitement diététique qui ont été reproduits trois fois avec dix oiseaux chacun. Deux mélanges différemment séchés de pulpe de manioc et de soja (chauffés secs et humides), mélangés à quatre (4) rapports différents, ont été soumis à deux types de méthodes de déshydratation 


\section{Nutritional evaluation of differently processed cassava-soya blends}

pour obtenir 12 types de mélanges. Ces mélanges ont ensuite été inclus dans les régimes des poulets à $15 \%$ dans un arrangement factorial $2 \times 2 \times 3$ pour obtenir 12 traitements diététiques. Huit semaines d'essais d'alimentation (phases de démarrage et de finition) ont été observées. Les mélanges ont été analysés chimiquement pour déterminer leurs compositions proximate, hydrocyanide (HCN) et unité d'inhibition de trypsine (TIU). Les paramètres de croissance (poids initial, poids final, gain de poids, apport alimentaire et ratio de conversion des aliments pour animaux) des oiseaux aux deux phases ont également été mesurés. Les résultats ont montré que le manioc frit et le soja chauffé humide à 50:50 ratio de mélange avaient la protéine brute la plus élevée (37,72\%) et l'énergie métabolisable (3 $314 \mathrm{kcal} / \mathrm{kg}$ ) avec un faible résidu de $H C N$ de $1,70 \mathrm{mg} / \mathrm{kg}$. Lors de la phase de démarrage, les oiseaux nourris selon un régime alimentaire contenant 50:50 de CSB avaient les poids finaux les plus élevés $(904,00 \mathrm{~g} / \mathrm{b})$ et le gain de poids $(31,08 \mathrm{~g} / \mathrm{b} / \mathrm{jour})$ tandis que ceux nourris avec un ratio de mélange de 80,20 g/ $/$ jour respectivement étaient les moins nombreux (839,00 g/b et 29,62 $\mathrm{g} / \mathrm{n} / \mathrm{j}$ our respectivement). Le gain de poids corporel le plus élevé $(p<0,05)$ par oiseau et par jour $(43,95 \mathrm{~g} / \mathrm{b} / \mathrm{j})$ et le plus faible ratio de conversion des aliments pour animaux $(2,56)$ ont été enregistrés chez les oiseaux nourris au mélange frit de soja chauffé à sec et de pulpe de manioc à 50:50 rapport de mélange à la phase de finition. La plus faible consommation d'aliments pour animaux a été enregistrée chez les oiseaux nourris au mélange frit de soja chauffé à sec et de pulpe de manioc à 80:20. On peut conclure que le remplacement de 15\% de soja crues chauffées à sec mélangées au manioc à 50:50 des mélanges CSB dans les régimes de poulets a entraîné un gain de poids plus élevé à la fois au démarrage et à la phase finale, tandis que la déshydratation par séchage au soleil et le rapport de mélange de 50:50 ont amélioré le ratio de conversion des aliments pour animaux à la phase de finition.

Mots-clés: Poulet à griller, mélange manioc-soja, performance de croissance, hydrocyanide, trypsine

\section{Introduction}

The cost of maize which has increased considerably in recent years due to competition with the human food industry, increased production of biofuel and droughts in some parts of Africa had led to increase in maize price (USDA, 2015) and some other conventional feedstuffs. These increase in the cost of conventional raw materials results in increased demand to find alternative feed resources that can be good alternatives to a proportion of these products in poultry diets at a lower cost of production. Maize makes up to $40-60 \%$ of the bulk of poultry feeds, as it is the major energy source used in the poultry industry. But due to insufficiency in its supplies, high prices and competition with the human food and biofuel industries as reported by means there is a continuous demand for alternative energy sources for poultry. And due to the availability of cassava in the tropical part of the world, cassava is becoming an increasingly important ingredient in poultry diets.

Compared with cereal grains, cassava is low in protein, and which is of poor quality with very low essential amino acid contents (Olugbemi et al., 2010). As a result, researchers (Tewe and Egbunike, 1992; Iyayi and Losel, 2001; Nagib and Sousa, 2007; Morgan and Choct, 2016) opined that cassava-based diets must be supplied with protein sources that provide an adequate supply of methionine and lysine, which can be costly, and can as well be supplemented with other amino acids (Adegbola, 1977). Other options for overcoming this problem include incorporating cassava leaves, seeds or cakes, which are richer in protein, into the diet (Ngiki et al., 2014), hence the reason for incorporating soybean into the diets in this study to make a Cassava-Soya blend. Cassava can as well be subjected to 
biofortification of micronutrients, such as vitamin $\mathrm{A}$, iron and zinc, since it is a crop that thrive in areas deficient in minerals and vitamins (Montagnac et al., 2009; Nnadi et al., 2010) which can cause it to be deficient. The utilisation of cassava according to Morgan and Choct (2016) is also limited by its high fibre, low energy content and the presence of anti-nutritional factors; primarily hydrocyanic acid (Gomez et al., 1988) which makes the need to improve the nutritional value of cassava food products through processing become a necessary intervention. With correct processing (sundrying, oven drying etc. after fermentation), the inclusion level of cassava in poultry diets could be increased.

The low protein content of cassava makes it insufficient in replacing maize adequately, and thus require protein fortification via oil seeds such as soybean - and the presence of anti-nutrients in both cassava and soybean brings about the need for finding a cheap and affordable processing method. This current study therefore aimed at evaluating the nutritional value of differently processed cassava-soya blends in the diets of broiler chickens.

\section{Materials and methods Study area}

The experiment was carried out at the Poultry Unit of the Directorate of University Farms (DUFARMS) of the Federal University of Agriculture, Abeokuta (FUNAAB), Ogun State Nigeria. The site is located in the rain forest vegetation zone of South-Western Nigeria on latitude $7^{0} 10^{\prime} \mathrm{N}$ and longitude $3^{0} 2^{\prime} \mathrm{E}$. The climate is tropical humid with a mean annual rainfall of $1037 \mathrm{~mm}$, mean temperature of $34.7^{\circ} \mathrm{C}$. Humidity of the experimental location is lowest $(37 \%-54 \%)$ at the peak of dry season in February and highest at the peak of the rainy season between June and September $(78 \%-85 \%)$. (Federal University of Agriculture
Abeokuta Meteorological Station).

Test ingredients and preparation of samples

Test ingredients for the experiments were cassava (Manihot esculenta Crantz) of the variety TMS 30572 and SoybeanSoybeans (Glycine max) of the variety TGX 923E. The cassava tubers were obtained from local farmers within Abeokuta metropolis, Ogun state, while the soya beans were obtained from International Institute of Tropical Agriculture (IITA), Ibadan. The cassava tubers were processed according to the procedures described by Quaye et al. (2009). They were peeled, washed and grated in a commercial grating machine. The grated cassava pulps were packed in hessian bags and allowed to ferment while dewatering gradually under pressure for 48 hours. Thereafter, the dewatered pulps were pulverized with hands and sifted on a local raffia made sieve to remove the fibres. The soybean seeds of the variety TGX 923E were sorted to ensure homogeneity of samples, washed, sun dried and divided into two, then subjected to two heat treatments (dry and wet heat treatments);

Dry heat treatment: Part of the cleaned raw soya beans was poured into a hot metal dry pan (common driers). The soya beans were dry heated by continuous stirring until the beans were slightly roasted to a goldenbrown colour, following the method of Cheva-Isarakul and Tangtaweewipat (1995). The dry heated soya beans were spread to cool before milling into full fat soya meal.

Wet heat treatment: The other part of the cleaned raw soybeansoybeans was poured into a vat containing 20 litres of boiling water per each batch of $10 \mathrm{~kg}$ of soya beans. The soya beans were allowed to boil at $100^{\circ} \mathrm{C}$ for 30 minutes according to the methods described by Kaankuka et al. (1996). Thereafter, the water was decanted and the boiled soya beans oven-dried before milling into full fat meal. 
Cassava-soya blends were then prepared from mixtures of sieved cassava pulps and full fat soya beans (dry heated and wet heated) in the following ratios: 50:50, 60:40 and 80:20 (Table 1). The resulting mixtures were then further subjected to two types of dehydration methods (sun drying or frying) to make twelve different Cassava-soya blend sample treatments as shown in Table 1.

Table 1: Processing techniques and mixing ratios of cassava-soya blends (CSB)

\begin{tabular}{|c|c|c|c|}
\hline Treatments & Components & Mixing ratio & Processing techniques \\
\hline $\mathrm{CDF}_{1}$ & $\mathrm{CP}+\mathrm{DHTS}$ & $50: 50$ & Frying \\
\hline $\mathrm{CDF}_{2}$ & $\mathrm{CP}+\mathrm{DHTS}$ & $60: 40$ & Frying \\
\hline $\mathrm{CDF}_{3}$ & $\mathrm{CP}+\mathrm{DHTS}$ & $80: 20$ & Frying \\
\hline $\mathrm{CDS}_{1}$ & $\mathrm{CP}+\mathrm{DHTS}$ & $50: 50$ & Sun drying \\
\hline $\mathrm{CDS}_{2}$ & $\mathrm{CP}+\mathrm{DHTS}$ & $60: 40$ & Sun drying \\
\hline $\mathrm{CDS}_{3}$ & $\mathrm{CP}+\mathrm{DHTS}$ & $80: 20$ & Sun drying \\
\hline $\mathrm{CWF}_{1}$ & $\mathrm{CP}+\mathrm{WHTS}$ & $50: 50$ & Frying \\
\hline $\mathrm{CWF}_{2}$ & $\mathrm{CP}+\mathrm{WHTS}$ & $60: 40$ & Frying \\
\hline $\mathrm{CWF}_{3}$ & $\mathrm{CP}+\mathrm{WHTS}$ & $80: 20$ & Frying \\
\hline $\mathrm{CWS}_{1}$ & $\mathrm{CP}+\mathrm{WHTS}$ & $50: 50$ & Sun drying \\
\hline $\mathrm{CWS}_{2}$ & $\mathrm{CP}+\mathrm{WHTS}$ & $60: 40$ & Sun drying \\
\hline $\mathrm{CWS}_{3}$ & $\mathrm{CP}+\mathrm{WHTS}$ & $80: 20$ & Sun drying \\
\hline
\end{tabular}

CP - cassava pulp, DHTS - dry heat-treated soya, WHTS - wet heat-treated soya

$\left(\mathrm{CDF}_{1}-\mathrm{CDF}_{3}\right)$ - Fried (cassava pulp+ dry heated soya beans) at 50:50, 60:40 and 80:20; (CDS $\left.1-\mathrm{CDS}_{3}\right)-$ Sun dried (cassava pulp+ dry heated soya beans) at 50:50, 60:40 and 80:20; (CWF $\left.\quad{ }_{1}-\mathrm{CWF}_{3}\right)-$ Fried (cassava pulp+ wet heated soya beans ) at 50:50, 60:40 and 80:20; (CWS $1-\mathrm{CWS}_{3}$ )- Sun dried (cassava pulp + wet heated soya beans) at 50:50, 60:40 and 80:20.

\section{Experimental birds and management}

The feeding trial was conducted with a total number of 360 day-old Cobb 500 broiler chicks. The birds were intensively managed on a deep litter system in two phases (the starter and the finisher phases). The starter phase lasted for four weeks (0-4weeks), while the finisher phase also lasted for four weeks (5-8 weeks). The deep littered pen and equipment were washed and disinfected prior to arrival of the birds. All the routine management practices including medications (vaccines and drugs) specified for Cobb 500 breed of chickens were strictly adhered to. Feed and water were supplied to the birds ad libitum. The experimental birds were managed under standard management conditions of broiler chicken rearing in the tropics.

\section{Experimental diets and layout}

The twelve dietary treatments were arranged in a $2 \times 2 \times 3$ factorial experimental design to have 2 heat treatments of soybean (wet and dry heat treatments), 2 dehydration methods of cassava-soya blends (sun drying and frying) and 3 mixing ratios of cassavasoya blends (50:50, 60:40, and 80:20). The cassava-soya blends (CSB) was included in the broiler chickens' diets at $15 \%$ inclusion. At the onset of the experiment, the 360 Cobb-500 one-day-old broiler chicks were randomly allotted to the 12 experimental groups (30 birds per treatment). Each treatment was replicated 3 times to have 10 chicks per replicate group on weight equalization bases. At the end of the starter phase, the experimental birds were mixed together and re-assigned on weight equalization bases to the same number of dietary treatment groups with the same number of replicates. This was done to remove any carryover effect of the starter phase to finisher phase. All diets were formulated following recommended procedures (NRC, 1994) as presented in Tables 2 and 3. 


\section{Amos, Kareem, Amos and Idowu}

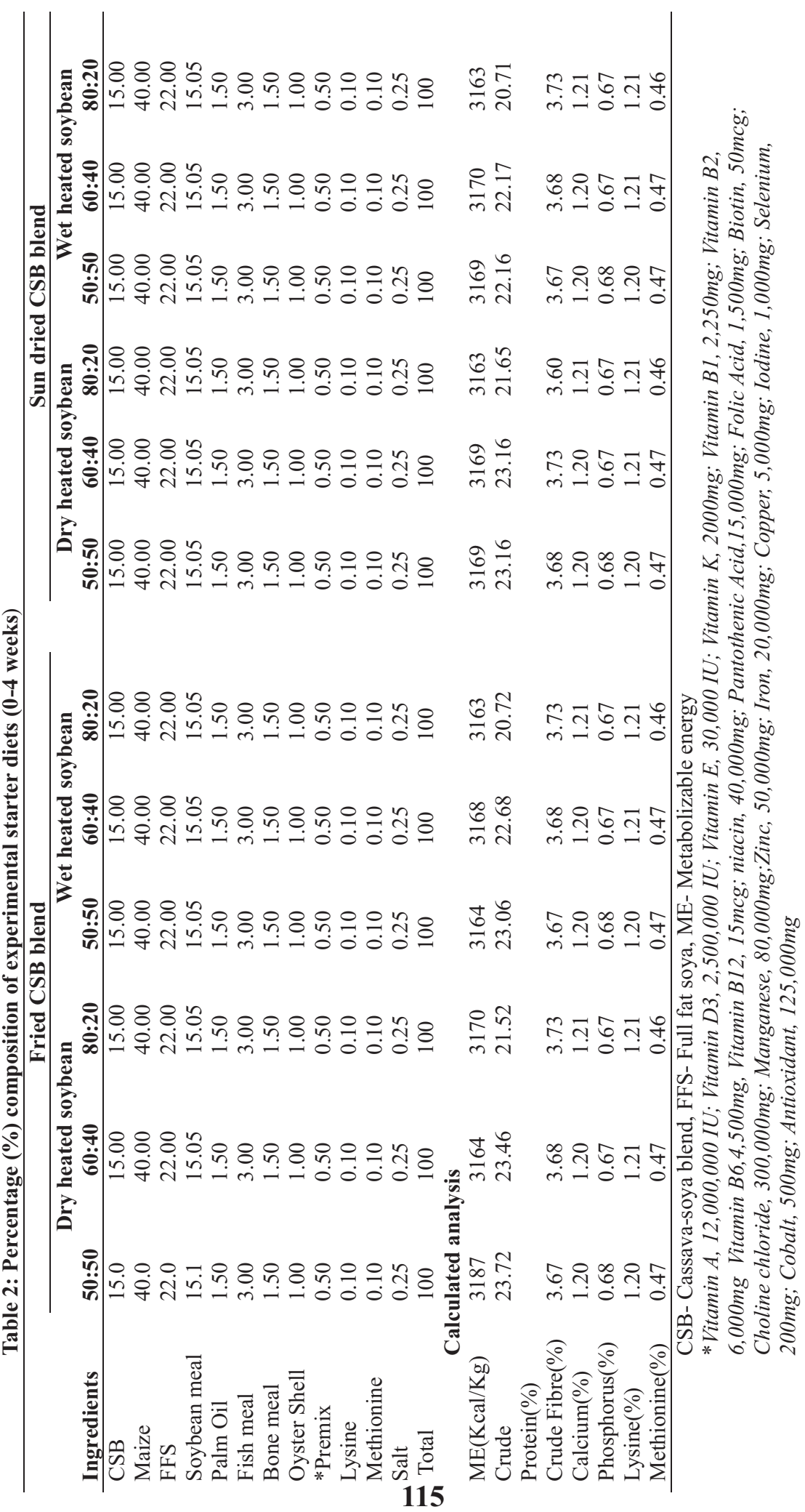


Nutritional evaluation of differently processed cassava-soya blends

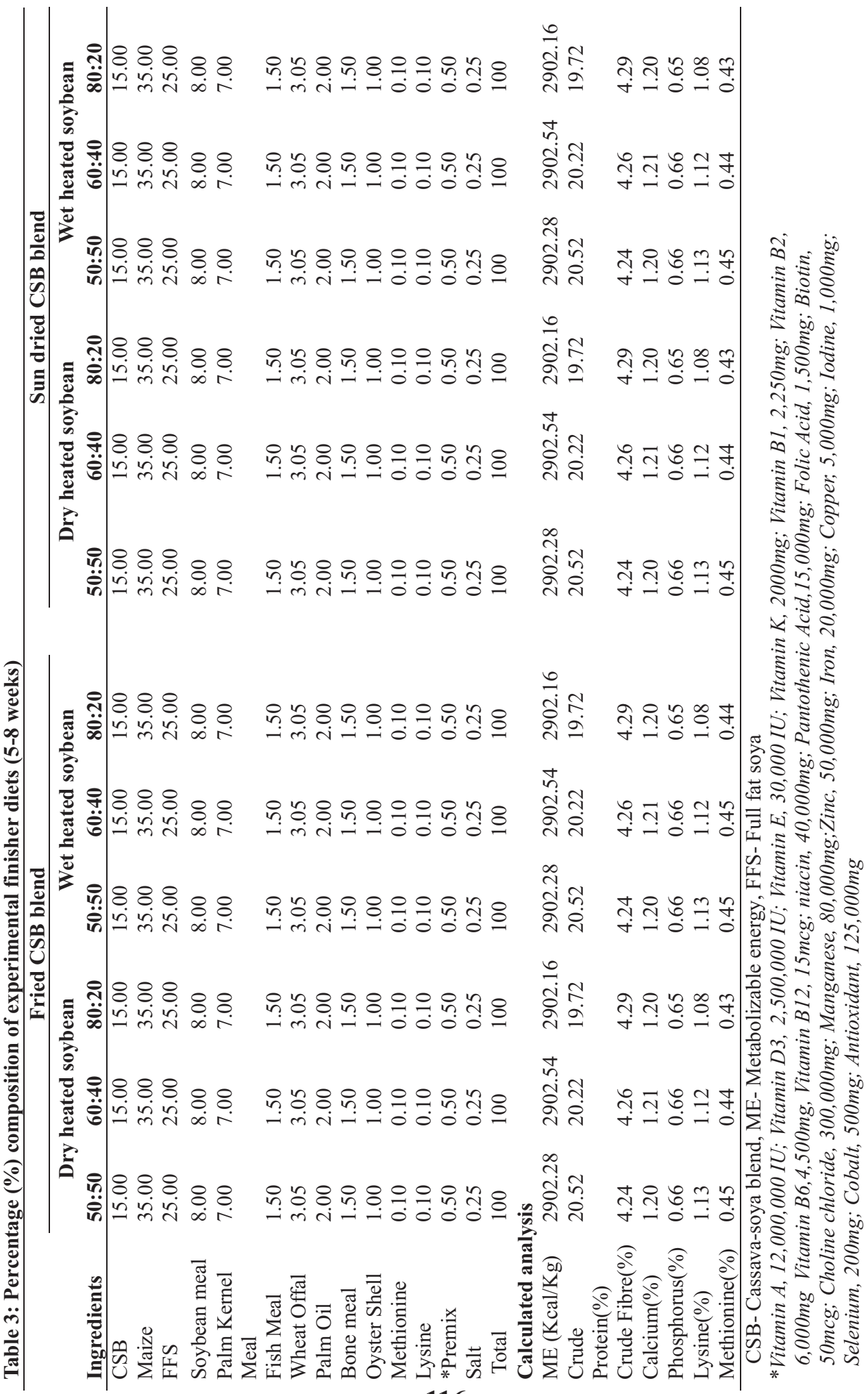

116 


\section{Amos, Kareem, Amos and Idowu}

\section{Data collection}

\section{Proximate composition of test ingredients}

Proximate composition (moisture, crude protein $[\mathrm{CP}]$, crude fibre $[\mathrm{CF}]$, ether extract [EE], Nitrogen Free Extract [NFE] and ash content) of the cassava-soya blends were determined by method described by AOAC (2005) while the metabolizable energy was calculated using Pauzenga (1985) equation as follows: $\mathrm{ME}=35 \mathrm{x} \% \mathrm{CP}+18.8 \times \% \mathrm{EE}+$ $35.5 \mathrm{x} \% \mathrm{NFE}$.

NB: ME- Metabolizable energy, CP-Crude protein, EE- Ether extract, NFE- Nitrogen free extract. Hydrogen cyanide $(\mathrm{HCN})$ content was determined according to the procedure of Anhwange (2004) while the trypsin inhibition unit (TIU) was also determined.

\section{Hydrogen cyanide (HCN) and Trypsin inhibitor unit (TIU) determination}

Alkaline titration procedure was adopted (Anhwange, 2004) for determination of the hydrogen cyanide. Ten grams of each of the ground 12 samples will be soaked in the mixture of $200 \mathrm{ml}$ of distilled water and 10 $\mathrm{cm}^{3}$ of orthophosphoric acid. The mixture was kept for 12 hours to release all the bound cyanide. The mixture was then distilled until $150 \mathrm{ml}$ of the distillate was collected. $20 \mathrm{ml}$ of the distillate were poured into a conical flask containing $40 \mathrm{ml}$ of distilled water. $8 \mathrm{ml}$ of ammonia solution (6 $\left.\mathrm{mol} / \mathrm{dm}^{3}\right)$ and $2 \mathrm{ml}$ of potassium iodide $(5 \%)$ solution was added. The mixture was then titrated with silver nitrate $\left(0.02 \mathrm{~mol} / \mathrm{dm}^{3}\right)$ to faint but permanent turbidity ( $1 \mathrm{ml} 0.02$ $\mathrm{mol} / \mathrm{dm} 3 \mathrm{AgNO} 3)$ is equivalent to $(1.08 \mathrm{mg}$ $\mathrm{HCN}$ ).

The percentage hydrocyanide was calculated with the formula: $\%$ Hydrocyanide $=\frac{\text { Titre } \times 10 \times 0.27 \times 100}{1000 \times \text { weight of sample }}$

Trypsin inhibitor was determined by weighing $0.2 \mathrm{~g}$ each of the 12 samples into a screw cap centrifuge tube. $10 \mathrm{ml}$ of $0.1 \mathrm{M}$ phosphate buffer was measured and the contents were shaken at room temperature for 1 hour on a UDY shaker. The suspension obtained were then centrifuged at $5000 \mathrm{rpm}$ for 5 minutes and filtered through whatman No. 42 filter paper. The volume of each was adjusted to $2 \mathrm{ml}$ with phosphate buffer. The test tubes were placed in a water bath, maintained at $37^{\circ} \mathrm{C} .6 \mathrm{ml}$ of $5 \%$ Trichloroacetic acid (TCA) solution was added to one of the tubes to serve as a blank. $2 \mathrm{mls}$ of casein solution were added to all of the tubes previously kept at $37^{\circ} \mathrm{C}$. They were then incubated for 20 minutes. The reaction was then stopped after 20 minutes by adding $6 \mathrm{ml}$ of TCA solution to the experimental tubes and shaken. The reaction was allowed to proceed for 1 hour at room temperature after which the mixture was then filtered through whatman No. 42 filter paper. Absorbance of filtrate from sample and trypsin standard solutions were read at $280 \mathrm{~nm}$. The trypsin inhibitor in $\mathrm{mg} / \mathrm{g}$ sample was then calculated using the formula:

TIU $\{\mathrm{mg} / \mathrm{g}\}=\underline{\text { A standard }- \text { A sample }} \quad \mathrm{x}$ Dilution factor

$0.19 \mathrm{x}$ weight of sample $1000 \mathrm{x}$ sample size

\section{Growth performance characteristics}

The live weight of birds per replicate was recorded on arrival and on weekly basis thereafter, using an electronic weighing scale. Afterwards weight gain was calculated by the subtraction of initial weight from the final weight. Feed intake of each replicate was calculated on a weekly basis by the subtraction of left over feed from the total feed supplied. Values obtained were used to compute feed conversion ratio by dividing the feed intake by weights gain.

\section{Statistical analysis}

Data obtained in this study were subjected to analysis of variance in a $2 \times 2 \times 3$ factorial arrangement, and were analysed using the general linear model procedure of SAS 9.1.3 computer software statistical package (SAS, 2002). Significant $(\mathrm{p}<0.05)$ means 


\section{Nutritional evaluation of differently processed cassava-soya blends}

were separated using Duncan's Multiple Range Test as contained in the procedure of the statistical package.

\section{Statistical model}

$\mathrm{Y}_{\mathrm{ijk}}=\mu+\mathrm{T}_{\mathrm{i}}+\mathrm{L}_{\mathrm{j}}+\mathrm{M}_{\mathrm{k}}+(\mathrm{TL})_{\mathrm{ij}}+(\mathrm{TM})_{\mathrm{ik}}+$ $(\mathrm{LM})_{\mathrm{jk}}+(\mathrm{TLM})_{\mathrm{ijk}}+\mathrm{o}_{\mathrm{ijk}}$

Where,

$\mathrm{Y}_{\mathrm{ijkl}}=$ Observed values of the dependent variable $\mu=$ Population mean

$\mathrm{T}_{\mathrm{i}}=$ Main effects of soybean heat treatments (Wet and dry heat treatments)

$\mathrm{L}_{\mathrm{j}}=$ Main effects of dehydration methods of cassava-soya blends (Sun-drying and frying)

$\mathrm{M}_{\mathrm{k}}=$ Main effects of mixing ratio of cassava-soya blends (50:50, 60:40, 80:20)

Table 4: Proximate composition of cassava-soya blends

\begin{tabular}{llllllllll}
\hline Samples & DM (\%) & $\begin{array}{l}\text { ME } \\
(\mathrm{Kcal} / \mathrm{kg})\end{array}$ & CP $(\%)$ & EE (\%) & CF (\%) & $\begin{array}{l}\text { Ash } \\
(\%)\end{array}$ & $\begin{array}{l}\text { NFE } \\
(\%)\end{array}$ & $\begin{array}{l}\text { HCN } \\
(\mathrm{mg} / \mathrm{kg})\end{array}$ & $\begin{array}{l}\text { TIU } \\
(\mathrm{mg} / \mathrm{g})\end{array}$ \\
\hline $\mathrm{CDF}_{1}$ & 70.23 & 3281.62 & 33.47 & 1.40 & 4.43 & 2.00 & 58.70 & 1.60 & 7.50 \\
$\mathrm{CDF}_{2}$ & 70.00 & 3319.98 & 31.75 & 1.11 & 4.51 & 1.00 & 61.63 & 1.61 & 7.40 \\
$\mathrm{CDF}_{3}$ & 68.64 & 3281.54 & 18.81 & 0.58 & 5.03 & 2.00 & 73.58 & 1.65 & 7.30 \\
$\mathrm{CDS}_{1}$ & 66.82 & 3279.56 & 35.72 & 1.35 & 4.48 & 2.00 & 56.45 & 1.68 & 7.80 \\
$\mathrm{CDS}_{2}$ & 68.64 & 3305.90 & 33.19 & 1.06 & 4.91 & 1.00 & 59.84 & 1.72 & 7.70 \\
$\mathrm{CDS}_{3}$ & 66.59 & 3270.30 & 20.10 & 0.48 & 5.37 & 2.00 & 72.05 & 1.76 & 7.60 \\
$\mathrm{CWF}_{1}$ & 70.00 & 3310.66 & 36.37 & 1.34 & 4.59 & 1.00 & 56.68 & 1.61 & 2.10 \\
$\mathrm{CWF}_{2}$ & 71.59 & 3317.61 & 34.65 & 1.08 & 4.55 & 1.00 & 58.72 & 1.61 & 2.00 \\
$\mathrm{CWF}_{3}$ & 69.36 & 3273.96 & 19.63 & 0.52 & 5.28 & 2.00 & 75.57 & 1.66 & 2.20 \\
$\mathrm{CWS}_{1}$ & 67.73 & 3314.58 & 37.72 & 1.34 & 4.47 & 2.00 & 55.47 & 1.70 & 2.60 \\
$\mathrm{CWS}_{2}$ & 67.95 & 3320.51 & 35.12 & 1.02 & 4.49 & 1.00 & 58.37 & 1.73 & 2.50 \\
$\mathrm{CWS}_{3}$ & 66.59 & 3272.56 & 20.07 & 0.47 & 5.32 & 2.00 & 72.14 & 1.77 & 2.30 \\
\hline $\mathrm{DW}_{3} \mathrm{Dry}$ & & & & & & & &
\end{tabular}

DM- Dry matter; ME-Metabolizable Energy; CP- crude protein; EE- Ether extract; CF- Crude fibre; NFE- Nitrogen free extract; HCN- Hydrocyanide; TIU-Trypsin inhibition unit

$\left(\mathrm{CDF}_{1} \mathrm{CDF}_{3}\right)-$ Fried (cassava pulp+ dry heated soya beans) at 50:50, 60:40 and 80:20; (CDS $\left.{ }_{1} \mathrm{CDS}_{3}\right)-$ Sun dried (cassava pulp+ dry heated soya beans) at 50:50, 60:40 and 80:20; (CWF-CWF 3 )- Fried (cassava pulp+ wet heated soya beans ) at 50:50, 60:40 and 80:20; (CWS-CWS $)$ - Sun dried (cassava pulp + wet heated soya beans) at 50:50, $60: 40$ and $80: 20$.

$(\mathrm{TL})_{\mathrm{ij}}=$ Interaction effects of heat treatments of soybean and dehydration methods of cassava-soya blends

$(\mathrm{TM})_{\mathrm{ik}}=$ Interaction effects of heat treatments of soybean and mixing ratio of cassava-soya blends

$(\mathrm{LM})_{\mathrm{jk}}=$ Interaction effects of dehydration methods of cassava-soya blends and mixing ratio of cassava-soya blends

$(\mathrm{TLM})_{\mathrm{ijk}}=$ Interaction effects of heat treatments of soybean, dehydration methods of cassava-soya blends and mixing ratio of cassava-soya blends

$\mathrm{o}_{\mathrm{ijkl}}=$ Random/residual error

\section{Results and discussion}

Proximate composition and anti-nutritional constituents of cassava-soya blends

The proximate composition of cassava- soya blends (CSB) is presented in Table 4. The analyses were carried out on dry matter (DM) basis. The proximate values (Crude protein, Ether extract, Crude fibre, Ash digestibility, Nitrogen free extract), hydrogen cyanide and Trypsin inhibition unit) values of the CSB ranged from 18.81$37.72 \%, 0.47-1.40 \%, 4.43-5.37 \%, 1-2 \%$, $55.47-75.57 \%, 1.60-1.77 \mathrm{mg} / \mathrm{kg}$ and $2.1-7.8$ $\mathrm{mg} / \mathrm{g}$, respectively. CSB containing dry heated soya beans and dehydrated by frying at 50:50 Sample $\left(\mathrm{CDF}_{1}\right)$ recorded the least values for crude fibre $(4.43 \%)$ and hydrogen cyanide $(1.60 \mathrm{mg} / \mathrm{kg})$ but recorded the highest value for ether extract $(1.40 \%)$. CSB containing dry heated soya beans and dehydrated by sun drying at 80:20 $\left(\mathrm{CDS}_{3}\right)$ had the least value for metabolizable energy (3270 kcal $/ \mathrm{kg})$ while 


\section{Amos, Kareem, Amos and Idowu}

CSB containing wet heated soya beans and dehydrated by sun drying at 60:40 $\left(\mathrm{CWS}_{2}\right)$ had the highest $(3320 \mathrm{kcal} / \mathrm{kg})$. CSB containing dry heated soya beans and dehydrated by sun drying at 80:20 ( $\left.\mathrm{CDS}_{3}\right)$ had the least dry matter $(66.59 \%)$ content and ether extract $(0.47 \%)$. CSB containing dry heated soya beans and dehydrated by frying at 80:20 $\left(\mathrm{CDF}_{3}\right)$ recorded the least value for crude protein (18.81\%) while CSB containing wet heated soya beans and dehydrated by sun drying at 50:50 (CWS $)$ had the highest crude protein $(37.72 \%)$ value. The hydrogen cyanide had the highest (1.77 mg/kg) and least (1.60 mg/kg) values in CSB dehydrated by sun drying and containing wet heated soya beans $\left(\mathrm{CWS}_{3}\right)$ and CSB containing dry heated soya beans and dehydrated by frying 50:50 $\left(\mathrm{CDF}_{1}\right)$ respectively. CSB containing dry heated soya beans and dehydrated by sun drying at 50:50 $\left(\mathrm{CDS}_{1}\right)$ recorded the highest value for trypsin inhibition unit $(7.80 \mathrm{mg} / \mathrm{g})$ while CSB containing wet heated soya beans and dehydrated by frying at 50:50 $\left(\mathrm{CWF}_{1}\right)$ recorded the least $(2.10 \mathrm{mg} / \mathrm{g})$ value.

Table 4: Proximate composition of cassava-soya blends

\begin{tabular}{llllllllll}
\hline Samples & DM $(\%)$ & $\begin{array}{l}\text { ME } \\
(\mathrm{Kcal} / \mathrm{kg})\end{array}$ & CP $(\%)$ & EE $(\%)$ & CF $(\%)$ & $\begin{array}{l}\text { Ash } \\
(\%)\end{array}$ & $\begin{array}{l}\text { NFE } \\
(\%)\end{array}$ & $\begin{array}{l}\text { HCN } \\
(\mathrm{mg} / \mathrm{kg})\end{array}$ & $\begin{array}{l}\text { TIU } \\
(\mathrm{mg} / \mathrm{g})\end{array}$ \\
\hline $\mathrm{CDF}_{1}$ & 70.23 & 3281.62 & 33.47 & 1.40 & 4.43 & 2.00 & 58.70 & 1.60 & 7.50 \\
$\mathrm{CDF}_{2}$ & 70.00 & 3319.98 & 31.75 & 1.11 & 4.51 & 1.00 & 61.63 & 1.61 & 7.40 \\
$\mathrm{CDF}_{3}$ & 68.64 & 3281.54 & 18.81 & 0.58 & 5.03 & 2.00 & 73.58 & 1.65 & 7.30 \\
$\mathrm{CDS}_{1}$ & 66.82 & 3279.56 & 35.72 & 1.35 & 4.48 & 2.00 & 56.45 & 1.68 & 7.80 \\
$\mathrm{CDS}_{2}$ & 68.64 & 3305.90 & 33.19 & 1.06 & 4.91 & 1.00 & 59.84 & 1.72 & 7.70 \\
$\mathrm{CDS}_{3}$ & 66.59 & 3270.30 & 20.10 & 0.48 & 5.37 & 2.00 & 72.05 & 1.76 & 7.60 \\
$\mathrm{CWF}_{1}$ & 70.00 & 3310.66 & 36.37 & 1.34 & 4.59 & 1.00 & 56.68 & 1.61 & 2.10 \\
$\mathrm{CWF}_{2}$ & 71.59 & 3317.61 & 34.65 & 1.08 & 4.55 & 1.00 & 58.72 & 1.61 & 2.00 \\
$\mathrm{CWF}_{3}$ & 69.36 & 3273.96 & 19.63 & 0.52 & 5.28 & 2.00 & 75.57 & 1.66 & 2.20 \\
$\mathrm{CWS}_{1}$ & 67.73 & 3314.58 & 37.72 & 1.34 & 4.47 & 2.00 & 55.47 & 1.70 & 2.60 \\
$\mathrm{CWS}_{2}$ & 67.95 & 3320.51 & 35.12 & 1.02 & 4.49 & 1.00 & 58.37 & 1.73 & 2.50 \\
$\mathrm{CWS}_{3}$ & 66.59 & 3272.56 & 20.07 & 0.47 & 5.32 & 2.00 & 72.14 & 1.77 & 2.30 \\
\hline $\mathrm{DW}^{2}$ & & & & & & &
\end{tabular}

DM- Dry matter; ME-Metabolizable Energy; CP- crude protein; EE- Ether extract; CF- Crude fibre; NFE- Nitrogen free extract; HCN- Hydrocyanide; TIU-Trypsin inhibition unit

$\left(\mathrm{CDF}_{1} \mathrm{CDF}_{3}\right)-$ Fried (cassava pulp+ dry heated soya beans) at 50:50, 60:40 and 80:20; (CDS $\left.{ }_{1} \mathrm{CDS}_{3}\right)-$ Sun dried (cassava pulp+ dry heated soya beans) at 50:50, 60:40 and 80:20; $\left(\mathrm{CWF}_{-}-\mathrm{CWF}_{3}\right)$ - Fried (cassava pulp+ wet heated soya beans ) at 50:50, 60:40 and 80:20; (CWS-CWS 3 )- Sun dried (cassava pulp + wet heated soya beans) at 50:50, 60:40 and 80:20.

Main effects of soybean heat treatments, dehydration methods and mixing ratio of CSB on performance of broiler chickens (0-8 weeks)

Table 5 shows the main effects of soybean heat treatments, dehydration methods and mixing ratio on performance characteristics of broiler chickens $(0-8$ weeks $)$. At $0-4$ weeks, the final weight and weight gain were significantly $(\mathrm{p}<0.05)$ affected by the heat treatments of soya beans in the CSB fed to starterbroiler chickens. Birds fed diets containing dry heated soybean had higher values for final weight and weight gain. At 5
-8 weeks, the initial weight and feed intake were as well significantly $(\mathrm{p}<0.05)$ affected by the heat treatment of soya beans in the CSB fed to finisherbroilers. Birds fed diets containing dry heated soybeans had higher initial weight and feed intake values compared to those fed wet heated soya beans. The final weight and weight gain were significantly $(\mathrm{pp}<0.05)$ affected by the dehydration methods of CSB fed to starter broiler chickens. Birds fed diets containing fried CSB had higher values of final weight and weight gain. At $5-8$ weeks, the initial weight, final weight, weight gain, feed intake and feed conversion ratio were all 


\section{Nutritional evaluation of differently processed cassava-soya blends}

significantly $(p<0.05)$ affected by the dehydration methods of CSB fed to finisherbroiler chickens. Birds fed diets containing fried CSB had higher values for all the parameters measured when compared to those fed diets containing sun dried CSB. At the starter phase, only the final weight and weight gain were significantly $(\mathrm{p}<0.05)$ affected by mixing ratio of CSB fed to the birds. Birds fed diets containing 50:50 mixing ratio of CSB had the highest values for final weight and weight gain while those fed diets containing
80:20 mixing ratio of CSB had the least values for the same parameters. The initial weight, final weight, weight gain, feed intake and feed conversion ratio were however significantly $(\mathrm{p}<0.05)$ affected at the finisher phase by the mixing ratio of CSB. Birds fed diets containing 50:50 mixing ratio of $\mathrm{CSB}$ had the highest values for initial weight, final weight, weight gain and feed intake. Birds fed 80:20 mixing ratio of CSB had the least values for initial weight, final weight, weight gain. The lowest FCR was recorded with birds fed 50:50 and 60:40 CSB mixing ratio.

\begin{tabular}{|c|c|c|c|c|c|c|c|c|c|c|c|c|c|}
\hline \multirow[b]{2}{*}{ Parameters } & \multicolumn{4}{|c|}{ Soybean heat treatments } & \multicolumn{4}{|c|}{ Dehydration methods of CSB } & \multicolumn{5}{|c|}{ Mixing ratios of CSB } \\
\hline & $\begin{array}{c}\text { Dry } \\
\text { heated }\end{array}$ & $\begin{array}{c}\text { Wet } \\
\text { heated }\end{array}$ & SEM & $\begin{array}{c}\text { p- } \\
\text { value }\end{array}$ & Fried & $\begin{array}{c}\text { Sun } \\
\text { dried }\end{array}$ & SEM & $\begin{array}{c}\text { p- } \\
\text { value }\end{array}$ & $50: 50$ & $60: 40$ & $80: 20$ & SEM & p-value \\
\hline \multicolumn{14}{|l|}{ 0-4 weeks } \\
\hline IW (g/b) & 40.14 & 40.17 & 0.088 & 0.219 & 40.39 & 40.43 & 0.036 & 0.470 & 40.43 & 40.38 & 40.41 & 0.044 & 0.684 \\
\hline $\mathrm{FW}(\mathrm{g} / \mathrm{b})$ & $902.00^{\mathrm{a}}$ & $898.00^{\mathrm{b}}$ & 15.000 & 0.003 & $908.00^{\mathrm{a}}$ & $846.00^{\mathrm{b}}$ & 10.483 & 0.000 & $904.00^{\mathrm{a}}$ & $889.00^{\mathrm{b}}$ & $839.00^{\mathrm{c}}$ & 12.838 & 0.004 \\
\hline $\begin{array}{l}\text { WG } \\
\text { (g/b/day) }\end{array}$ & $30.78^{\mathrm{a}}$ & $30.60^{\mathrm{b}}$ & 0.381 & 0.021 & 30.98 & 28.75 & 0.934 & 0.021 & $31.08^{\mathrm{a}}$ & $30.03^{\mathrm{ab}}$ & $29.62^{\mathrm{b}}$ & 0.467 & 0.007 \\
\hline FI (g/b/day) & 44.19 & 44.18 & 0.476 & 0.988 & 49.42 & 48.95 & 0.476 & 0.988 & 49.49 & 49.82 & 48.24 & 1.165 & 0.148 \\
\hline FCR & 1.45 & 1.44 & 0.027 & 0.068 & 1.60 & 1.71 & 0.066 & 0.068 & 1.60 & 1.65 & 1.68 & 0.035 & 0.150 \\
\hline \multicolumn{14}{|l|}{ 5-8 weeks } \\
\hline $\mathrm{IW}(\mathrm{g} / \mathrm{b})$ & $902.00^{\mathrm{a}}$ & $898.00^{b}$ & 15.222 & 0.047 & $908.00^{\mathrm{a}}$ & $846.00^{\mathrm{b}}$ & 12.000 & 0.000 & $904.00^{\mathrm{a}}$ & $889.00^{\mathrm{b}}$ & $839.00^{c}$ & 13.374 & 0.020 \\
\hline $\mathrm{FW}(\mathrm{g} / \mathrm{b})$ & 2090.67 & 2078.33 & 30.666 & 0.250 & $2140.24^{\mathrm{a}}$ & $1880.56^{\mathrm{b}}$ & 31.333 & 0.000 & $2170.28^{\mathrm{a}}$ & $2110.23^{b}$ & $1900.42^{\mathrm{c}}$ & 35.454 & 0.000 \\
\hline $\begin{array}{l}\text { WG } \\
\text { (g/b/day) }\end{array}$ & 42.45 & 42.18 & 0.900 & 0.233 & $44.00^{\mathrm{a}}$ & $37.91^{\mathrm{b}}$ & 1.086 & 0.000 & $45.39^{\mathrm{a}}$ & $43.94^{\mathrm{b}}$ & $38.84^{c}$ & 0.779 & 0.000 \\
\hline $\mathrm{FI}$ (g/b/day) & $111.27^{\mathrm{a}}$ & $110.58^{\mathrm{b}}$ & 1.646 & 0.025 & $118^{\mathrm{a}}$ & $100.81^{\mathrm{b}}$ & 1.667 & 0.000 & $116.25^{\mathrm{a}}$ & $113.02^{\mathrm{ab}}$ & $109.09^{\mathrm{b}}$ & 1.399 & 0.008 \\
\hline FCR & 2.61 & 2.62 & 0.520 & 0.481 & $2.68^{\mathrm{a}}$ & $2.59^{\mathrm{b}}$ & 0.035 & 0.000 & $2.58^{\mathrm{b}}$ & $2.57^{\mathrm{b}}$ & $2.78^{\mathrm{a}}$ & 0.043 & 0.001 \\
\hline
\end{tabular}

Interaction effects of soybean heat treatments and dehydration methods, soybean heat treatments and mixing ratio of CSB, dehydration methods and mixing ratio of CSB on performance of broiler chickens (0-8 weeks)

Interaction effects of soybean heat treatments and dehydration methods of CSB on performance of broiler chickens is presented in Table 6. All the parameters measured; initial weight, final weight, weight gain, feed intake and feed conversion ratio were not significantly $(p>0.05)$ affected by the interaction of heat treatments and dehydration methods of CSB fed to broiler chickens both at starter and finisher phases. Table 7 shows the interaction effects of soybean heat treatments and mixing ratio of CSB on performance of broiler chickens (0-8 weeks). All the parameters measured were not significantly $(p>0.05)$ affected by the interaction of soybean heat treatment and mixing ratio of CSB at both phases. Nevertheless, birds fed toasted soya beans at 50:50 mixing ratio of experimental diet had the highest values for final weight, weight gain and feed intake. Table 8 shows the interaction effects of dehydration methods and mixing ratio of CSB on performance of broiler chickens (0-8 weeks). At $0-4$ weeks, all the parameters measured, initial weight, final weight, weight gain, feed intake and feed conversion ratio were not significantly $(p>0.05)$ affected by the interaction of dehydration methods and mixing ratios of 
CSB fed to starter broilers. At finisher phase however, the feed intake and feed conversion ratio of the birds were significantly $(\mathrm{p}<0.05)$ affected by the interactions of dehydration methods and mixing ratio of CSB. Birds fed diets containing fried CSB at 50:50 mixing ratios had the highest $(\mathrm{p}<0.05)$ feed intake and best FCR while those fed sundried CSB at 80:20 mixing ration

Table 6: Interaction effects of soybean heat treatments and dehydration methods of CSB on performance of broiler chickens (0-8 weeks)

\begin{tabular}{|c|c|c|c|c|c|c|}
\hline \multirow[b]{2}{*}{ Parameters } & \multicolumn{2}{|c|}{ Fried CSB } & \multicolumn{2}{|c|}{ Sun dried CSB } & \multirow[b]{2}{*}{ SEM } & \multirow[b]{2}{*}{$\mathrm{p}$-value } \\
\hline & $\begin{array}{c}\text { Dry heated } \\
\text { soybean }\end{array}$ & $\begin{array}{c}\text { Wet heated } \\
\text { soybean }\end{array}$ & $\begin{array}{c}\text { Dry heated } \\
\text { soybean }\end{array}$ & $\begin{array}{c}\text { Wet heated } \\
\text { soybean }\end{array}$ & & \\
\hline \multicolumn{7}{|l|}{ 0-4 weeks } \\
\hline IW (g/b) & 40.43 & 40.44 & 40.34 & 40.41 & 0.051 & 0.596 \\
\hline $\mathrm{FW}(\mathrm{g} / \mathrm{b})$ & 923 & 881 & 894 & 832 & 14.825 & 0.193 \\
\hline WG (g/b/day) & 31.68 & 29.18 & 30.83 & 28.67 & 0.539 & 0.502 \\
\hline FI (g/b/day) & 48.95 & 49.43 & 49.90 & 48.46 & 0.673 & 0.166 \\
\hline FCR & 1.55 & 1.69 & 1.63 & 1.69 & 0.038 & 0.772 \\
\hline \multicolumn{7}{|l|}{ 5-8 weeks } \\
\hline IW $(\mathrm{g} / \mathrm{b})$ & 923 & 881 & 894 & 832 & 15.443 & 0.353 \\
\hline $\mathrm{FW}(\mathrm{g} / \mathrm{b})$ & 2250 & 2120.65 & 2130.54 & 1950.89 & 40.939 & 0.566 \\
\hline WG (g/b/day) & 47.37 & 44.27 & 44.16 & 40.01 & 0.899 & 0.256 \\
\hline FI (g/b/day) & 119.37 & 112.87 & 117.46 & 105.95 & 1.697 & 0.304 \\
\hline FCR & 2.55 & 2.54 & 2.66 & 2.64 & 0.050 & 0.416 \\
\hline
\end{tabular}

FCR- Feed Conversion Ratio; IW- Initial weight; FW- Final weight; FI- Feed intake recorded the least feed intake. Birds fed diets containing sundried CSB at 50:50, 60:40 and 80:20 mixing ratios had similar values for FCR.

Table 7: Interaction effects ofsoybean heat treatments and mixing ratio of CSB on performance of broiler chickens ( $0-8$ weeks)

\begin{tabular}{lcccccccc}
\hline \multicolumn{7}{c}{ Dry heated soybean } & \multicolumn{7}{c}{ Wet heated soybean } \\
Parameters & $\mathbf{5 0 : 5 0}$ & $\mathbf{6 0 : 4 0}$ & $\mathbf{8 0 : 2 0}$ & $\mathbf{5 0 : 5 0}$ & $\mathbf{6 0 : 4 0}$ & $\mathbf{8 0 : 2 0}$ & SEM & p-value \\
\hline $\mathbf{0 - 4}$ weeks & & & & & & & & \\
IW $(\mathrm{g} / \mathrm{b})$ & 40.45 & 40.41 & 40.46 & 40.42 & 40.35 & 40.36 & 0.088 & 0.848 \\
FW $(\mathrm{g} / \mathrm{b})$ & 943 & 916 & 847 & 865 & 861 & 832 & 18.156 & 0.244 \\
WG (g/b/day) & 31.68 & 30.32 & 29.29 & 30.48 & 29.32 & 28.21 & 0.660 & 0.909 \\
FI (g/b/day) & 48.75 & 48.50 & 48.32 & 49.24 & 49.14 & 48.16 & 1.165 & 0.242 \\
FCR & 1.54 & 1.60 & 1.65 & 1.63 & 1.66 & 1.70 & 0.046 & 0.464 \\
$\mathbf{5 - 8}$ weeks & & & & & & & & \\
IW (g/b) & 943 & 916 & 847 & 865 & 861 & 832 & 18.913 & 0.965 \\
FW (g/b) & 2210 & 2160.12 & 1980.88 & 2140.42 & 2050 & 1975.81 & 40.139 & 0.270 \\
WG (g/b/day) & 45.99 & 43.52 & 40.49 & 45.78 & 42.36 & 40.15 & 1.101 & 0.177 \\
FI (g/b/day) & 118.56 & 115.72 & 112.49 & 115.54 & 111.25 & 107.46 & 1.978 & 0.953 \\
FCR & 2.59 & 2.64 & 2.78 & 2.58 & 2.66 & 2.67 & 0.062 & 0.122 \\
\hline
\end{tabular}

FCR- Feed Conversion Ratio; IW- Initial weight; FW- Final weight; FI- Feed intake

Interaction effects of soybean heat treatments, dehydration methods and mixing ratio of $C S B$ on performance of broiler chickens (0-8 weeks)

The interaction effects of soybean heat treatments, dehydration methods and mixing ratio of $\mathrm{CSB}$ on performance characteristics of broiler chickens is presented in Table 9. All the parameters measured were not significantly $(p>0.05)$ affected by the interactions of soybean heat treatments, dehydration methods and mixing ratio of CSB fed to the birds at starter phase. At the finisher phase, the interactions of soybean heat treatments, dehydration methods and mixing ratio of CSB significantly $(p<0.05)$ affected the final weight, weight gain, feed intake and FCR of the birds. Birds fed $\mathrm{CDF}_{3}$ recorded the lowest feed intake (100.84 g/b/day) and FCR (2.44), while those fed $\mathrm{CDS}_{3}$ gained 


\section{Nutritional evaluation of differently processed cassava-soya blends}

Table 8: Interaction effects of dehydration methods and mixing ratio of CSB on performance of broiler chickens (0-8 weeks)

\begin{tabular}{|c|c|c|c|c|c|c|c|c|}
\hline \multirow[b]{2}{*}{ Parameters } & \multirow[b]{2}{*}{$50: 50$} & \multicolumn{2}{|c|}{ Fried CSB } & \multicolumn{3}{|c|}{ Sun dried CSB } & \multirow[b]{2}{*}{ SEM } & \multirow[b]{2}{*}{ p-value } \\
\hline & & $60: 40$ & $80: 20$ & $50: 50$ & $60: 40$ & $80: 20$ & & \\
\hline \multicolumn{9}{|l|}{ 0-4 weeks } \\
\hline IW (g/b) & 40.41 & 40.38 & 40.37 & 40.45 & 40.38 & 40.44 & 0.086 & 0.884 \\
\hline $\mathrm{FW}(\mathrm{g} / \mathrm{b})$ & 931.00 & 918.00 & 875.00 & 878.00 & 859.00 & 833.00 & 19.677 & 0.857 \\
\hline WG (g/b/day) & 31.64 & 30.99 & 30.13 & 29.53 & 29.65 & 28.13 & 0.934 & 0.779 \\
\hline FI (g/b/day) & 50.18 & 50.12 & 48.58 & 49.01 & 48.93 & 47.90 & 0.824 & 0.242 \\
\hline FCR & 1.58 & 1.61 & 1.62 & 1.66 & 1.65 & 1.70 & 0.064 & 0.347 \\
\hline \multicolumn{9}{|l|}{ 5-8 weeks } \\
\hline IW (g/b) & 931.00 & 918.00 & 875.00 & 878.00 & 859.00 & 833.00 & 26.748 & 0.877 \\
\hline $\mathrm{FW}(\mathrm{g} / \mathrm{b})$ & 2270.15 & 2170.42 & 2080.12 & 1980.78 & 1960.75 & 1830.89 & 44.139 & 0.881 \\
\hline WG (g/b/day) & 47.83 & 44.75 & 43.52 & 40.05 & 39.83 & 35.77 & 1.557 & 0.317 \\
\hline FI (g/b/day) & $119.69^{a}$ & $117.51^{\mathrm{ab}}$ & $117.36^{\mathrm{ab}}$ & $113.55^{b}$ & $109.28^{b c}$ & $102.71^{\mathrm{c}}$ & 2.797 & 0.042 \\
\hline FCR & $2.50^{\mathrm{b}}$ & $2.62^{\mathrm{ab}}$ & $2.67^{\mathrm{ab}}$ & $2.83^{\mathrm{a}}$ & $2.79^{\mathrm{a}}$ & $2.86^{\mathrm{a}}$ & 0.068 & 0.012 \\
\hline
\end{tabular}

\section{Discussion}

The proximate composition of cassavasoya blends (CSB) revealed that the energy values ranged from (3272 to $3320 \mathrm{kcal} / \mathrm{kg})$. Though the inclusion ratio of cassava in the blends differs, there was a similarity in the energy values of the blends prepared. This may be due to the fact that soya beans are also a high source of energy $(3,300 \mathrm{kcal} / \mathrm{kg})$ as reported by (Aduku, 2005). The energy values of blends obtained in this study were slightly higher than the reported value (3150 kcal $/ \mathrm{kg}$ ) of NIAS (2020). The crude protein values obtained from this study ranged from (18.81 to $37.72 \%$ ), which falls within the range reported by Eruvbetine and Adejobi (1999). Fasuyi and Aletor (2005) reported $42.3 \%$ crude protein for cassava leaf protein concentrate while Iheukwumere et al. (2008) reported 25.10 $\%$ crude protein for cassava leaf meal. It was observed that in blends where raw soya beans were wet heated, higher protein levels were recorded than when they were dry heated. This may be due to uneven high temperatures employed during toasting which might have slightly denatured some of the amino acids of the soybeansoybeans thus making it unavailable for detection during analysis as reported by Eruvbetine and Adejobi (1999). The highest fat contents were obtained when the inclusion level of soya bean was $50 \%$ and the least values were obtained when the inclusion level was $20 \%$ which makes the fat contents dependent on the level of inclusion of soya beans. The high fat content recorded in 50\% inclusion of soya beans may be due to the high oil content in soybean seeds. The crude fibre values (4.43 to 5.31 ) \% falls within the range reported by Eruvbetine and Adejobi (1999) and was highest with blends containing $80 \%$ cassava, thereby making the crude fibre values dependent on the level of inclusion of cassava. The cyanide contents $(1.60 \mathrm{mg} / \mathrm{kg}$ to $1.72 \mathrm{mg} / \mathrm{kg})$ was generally lower than the optimum tolerance level $(100 \mathrm{mg} / \mathrm{kg} \mathrm{DM})$ recommended for livestock feeding by Tewe (1997). The cyanide levels of blends (CDS and CWS) which were higher than those of blends (CDF and CWF) could infer that frying is more effective in lowering cyanide levels compared to sun drying. The Trypsin Inhibitor Unit (TIU) values of blends CWF and CWS were lower compared to those of blends CDF and CDS, and falls within the range reported by Ari et al. (2012). This may be due to the fact that soybeans in these blends were subjected to more heat 


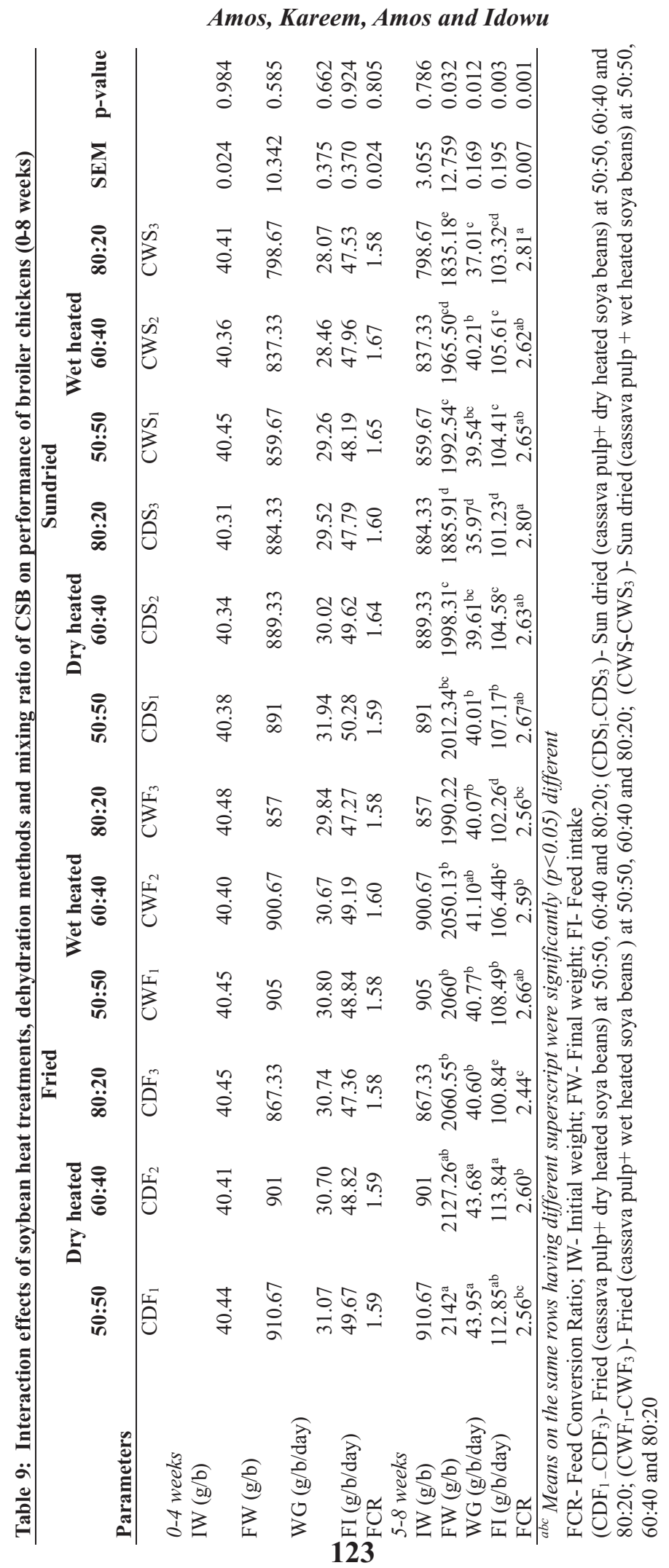




\section{Nutritional evaluation of differently processed cassava-soya blends}

treatments than the other blends (i.e. they were wet heated, oven dried and then subjected to either frying or sun drying).

At the starter phase, birds fed diets containing 50:50 mixing ratio of CSB had the highest final weights $(904.00 \mathrm{~g} / \mathrm{b})$ and weight gain ( $31.08 \mathrm{~g} / \mathrm{b} /$ day) while those fed diets containing 80:20 mixing ratio of CSB were least. As reported by Morgan and Choct (2016), wide variation has been observed between studies with regards to the success of feeding cassava meal to poultry. Early research, such as McMillan and Dudley (1941) and Vogt (1966), found that inclusion of cassava in poultry diets reduced performance. However, later studies, such as Khajarern and Khajarern (1992), Tewe and Egbunike (1992), Aderemi et al. (2000) and more recent Ogunwole et al. (2016), found more encouraging results, likely due to increased awareness of how to balance the nutrients and the negative impact of HCN. The favourable result observed with the final weight and weight gain of birds fed 50:50 mixing ratio of CSB could be as a result of the impact of processing methods of the cassava and the incorporation of processed soybean to form a blend.

Feed intake decreased as the level of inclusion of cassava increased at the finisher phase, and was lowest for blends containing 80:20 mixing ratio of CSB. This could be an indication of the adequate energy contents of these diets as birds feed to satisfy their energy requirements, as this agrees with the findings of Hassan et al. (2012) and that of Ukachukwu (2005) who reported a significant difference in daily feed intake of birds when cassava root meal was fed. Omekan (1994) also reported a drop in feed intake of birds fed cassava leaf meal which could be due to the fact that the leaf meal imparted unpalatable taste to the feed which consequently inhibited the birds from consuming adequate quantities. Also, the feed intake of birds fed sun dried CSB decreased significantly as the inclusion level of cassava increased at both starter and finisher phases. This is as well in line with the findings of Hassan et al. (2012) who fed broiler chickens graded levels of sun-dried cassava root meal. The best FCR was observed in the birds fed dry heated soya beans in fried CSB at 80:20 inclusion ratios $\left(\mathrm{CDF}_{3}\right)$. The reason for this could not be adjudged. At the finisher phase, birds on 50:50 inclusion level of CSB had the highest weight gain which was at par with birds on 60:40 inclusion level of CSB and were significantly higher than the rest of the treatments. This supports the findings of Montilla (1977) who reported a significant difference in the daily weight gain and feed conversion ratio when cassava root meal was added to the diets of broilers at graded levels. Authors (Gomez et al., 1988; Eruvbetine and Afolami, 1992) reported that inclusion of cassava root meal at levels up to $30 \%$ in diets for broilers had no detrimental effect on body weight.

Conclusion and recommendation

Based on the result of this study, it can be concluded that replacing $15 \%$ inclusion fried CSB blend of dry heated raw soya beans mixed with cassava at 50:50 of CSB blends in diets of broiler chickens resulted in higher weight gain at both starter and finisher phase, while dehydration by sun drying and 50:50 mixing ratio improved the feed conversion ratio of the birds at finisher phase. Sundried blend of cassava and wet heated soybeans, mixed at 50:50 ratio yielded the highest CP $(37.72 \%)$ and metabolizable energy $(3314 \mathrm{kcal} / \mathrm{kg})$ with low hydrocyanide residue of $1.70 \mathrm{mg} / \mathrm{kg}$, which is recommended for maize replacement of up to $15 \%$. Further study is as well recommended to be carried out to establish a threshold to which this blend can replace maize in poultry diet. 
References

Adegbola, A. A. 1977. Methionine as an additive to cassava-based diets. In: Mestel, B., Graham M., editors. Cassava as animal feed. Proceedings of a workshop held at the University of Guelph, 18-20 April. Ottawa, Canada: Ottawa, International Development Research Centre; p. 9-17.

Aderemi, F. A., Tewe, O.O. and Adesehinwa, A.O.K. 2000 . Utilization of cassava root and leaves in diets for layers. Trop. Vet. 18:213-219.

Aduku, A.O. 2005. Tropical Feedstuffs Analysis Table. Department of Animal Sciences, Ahmadu Bello University, Zaria, Nigeria.

Anhwange, B. A., Ajibola, V. O., Oniye, S. J. 2004. Chemical Studies of the Seeds of Moringa oleifera (Lam) and Detarium microcarpum (Guill and Sperr). Journal of Biological $S \quad c \quad i \quad e \quad n \quad c \quad e \quad s$ https://doi.org/10.3923/jbs.2004.7 11.715

AOAC. 2005. Official Methods of Analysis, 18th edition. Association of Official Analytical Chemist, Washington DC.

Ari, M.M., Ayanwale, B.A., Adama, T.Z. and Olatunji, E.A. 2012. Effect of different fermentation method on growth indices and serum profile of broiler chickens. Journal of Biology, Agriculture and Healthcare, 2(5):78-86

Cheva-Isarakul, B. and Tangtaweewipat, S. 1995. Utilization of full fat soyabean in poultry diets broilers. Asian J. Agric. Sci., 8: 89-95

Cheva-Isarakul, B. and Tangtaweewipat, S. 1995. Utilization of full fat soyabean in poultry diets broilers. Asian Journal of Agricultural $S c i e n c$ e $s$ 8:8 9 - 95 https://www.animbiosci.org/uploa d/pdf/8-14.pdf

Eruvbetine, D. and Adejobi, P.K. 1999. Preparation of Cass-Soya concentrate for inclusion in poultry diets (in-vitro studies). Nig.J.Anim.ProdNigerian Journal of Animal Production. 27(1):50-54.

Eruvbetine, D. and Afolami, C.A. 1992. Economic evaluation of cassava (Manihot esculenta) as a feed ingredient for broilers. Proc. XIXth World's Poultry Congress Amsterdam, Netherlands. 3:532535

Fasuyi, A.O. and Aletor, V.A. 2005. Protein replacement value of cassava (Manihot esculenta, Crantz) leaf protein concentrate (CLPC) in broiler starter: Effect on performance, muscle growth, haematology and serum metabolites. International Journal of Poultry Science, 4: 339-349.

Gomez, G., Aparicio, M. and Wilhita, C.C. 1988. Relationship between dietary cassava cyanide levels and broiler performance. Nutr. Reports Intl.37(1):6-75.

Gomez, G., Aparicio, M., Wilhita, C.C. 1988. Relationship between dietary cassava cyanide levels and broiler performance. Nutr. Reports Intl. 37(1):66-75.

Hassan, A., Tamburawa, M., Alponsus, C., Yusuf, J. 2012. Studies on growth, organs weight and haematological parameters of broiler chicken fed graded level of sun-dried cassava root meal. Bayero J. Pure Appl. Sci. 5(1): 98102 doi:10.4314/bajopas.v5i1.18.

Iheukwumere, F.C., Ndubusi, E.C., Mazi, E.A. and Onyekwere M.U. 2008. Performance, nutrient utilization and organ characteristics of broiler chickens 
fed cassava leaf meal (Manihot esculenta crantz). Pakistan Journal of Nutrition 7(1): 13-16

Iyayi, E.A., Losel, D.M. 2001. Protein enrichment of cassava by-products through solid state fermentation by fungi. JFeed Tech Afr. 6:116-118.

Kaankuka, F. G., Balogun, T. F. and Tegbe, T. S. B. 1996. Effect of duration of cooking of full fat soya beans on proximate analysis, level of anti-nutritional factors and digestibility by weaning pigs. Animal Feed Science and Technology 62: 229-237.

Khajarern, S. and Khajarern, J.M. 1992. Use of cassava products in poultry feeding. In: Proceedings of roots, tubers, plantains and bananas in animal feeding. Rome: FAO; 1992.

McMillan, A.M. and Dudley, F.G. 1941. Potato meal, tapioca meal and town waste in chicken rations. Poult $J$, 26:191-194. In: Morgan, N.K., Choct, M. 2016. Cassava: Nutrient composition and nutritive value in poultry diets. Anim. Nutr. 2:253260 https://doi.org/10.1016/j.aninu.20 16.08.010

Montagnac, J.A., Davis, C.R., Tanumihardjo, S.A. 2009. Nutritional value of cassava for use as a staple food and recent advances for improvement. Compr Rev Food Sci Food Saf. 8(3):181-194.

Montilla, J. 1977. Cassava in the nutrition of Broiler as Animal feed: proceeding of a workshop held at the University of Guelph, 18th20th April 1977. pp.43-50

Morgan, N.K., Choct, M. 2016. Cassava: Nutrient composition and nutritive value in poultry diets. Anim. Nutr. $2: \begin{array}{lllllll}2 & 5 & 3 & - & 2 & 6 & 1\end{array}$. https://doi.org/10.1016/j.aninu.20 16.08.010
Nagib, M.A., Sousa, M.V. 2007. Amino acid profile in cassava and its interspecific hybrid. Genet $\mathrm{Mol}$ Res. 6:292-297.

National Research Council. 1994. Nutrient requirements of poultry ( $9^{\text {th }}$ revised edition). National Academy Press, Washington, DC.

Ngiki, Y.U., Igwebuike, J.U., Moruppa, S.M. 2014. Utilisation of cassava products for poultry feeding: a review. Int JSci Tech. 2(6):48-59.

NIAS, 2020. 2020 National listing of approved feed ingredients for feedmills in Nigeria. Nigerian Institute of Animal Science. NIAS/RA/LAFI-2020

Nnadi, P.A., Omeke, B.C., Okpe, G.C. 2010. Growth and reproductive performances of weaner pigs fed maize replaced cassava diet. Anim Res Int. 70(3):1257-1263.

Ogunwole, O. A., Abayomi, F. D., Oladimeji, S. O, Olumide, M. D., Lawal, H. O., Idowu, A. I., Mosuro, A. O., Kulakow, P. O., Iluebey, $P$ and Tewe, O. O. 2017. Performance, serum biochemical indices and crude protein utilization by broiler chickens fed diets based on two varieties of cassava (Manihot esculenta Crantz) grits I Finisher Phase. Nigerian Journal of Animal Production, 44 (1): 162-174

Olugbemi, T.S., Mutayoba, S.K., Lekule, F.P. 2010. Effect of Moringa (Moringa oleifera) inclusion in cassava-based diets fed to broiler chickens. Int. J. Poult. Sci. 9(4):363-367.

Omekan, V.N. 1994. Studies on Nutrition and health implications of dietary inclusion of dried poultry waste for broilers. MSc. Thesis, Federal University of Technology, Owerri, Nigeria. 
Quaye, W., Gayin, J., Yawson, I. and Plahar, W.A. 2009. Characteristics of various cas s a a processing methods and the adoption requirements in Ghana. Journal of Root Crops. 35 (1): 59-68

SAS Institute. 2002. SAS User's Guide: Statistics. SAS Institute Inc. Cary NC.

Tewe, O.O. 1997. Microbial degradation of cassava residues and their utilization for livestock feeding. African Journal of Root and Tuber, 2(1\&2):129-131

Tewe, O.O. and Egbunike, G.N. 1992. Utilization of cassava in nonruminant livestock feeds. In: Hahn SK, Reynolds L, Egbunike GN, editors. Cassava as livestock feed in Africa. Proceedings of IITA/ILCA/University of Ibadan workshop on the potential utilisation of cassava as livestock feed in Africa; 1992. p. 28-38.
Ukachukwu, S. N. 2005. Studies on the nutritive value of composite cassava pellets for poultry: Chemical composition and metabolizable energy. Livestock Research for Rural Development 17: 125.

USDA. 2015. World agricultural supply and $\mathrm{d}$ e $\mathrm{m} \mathrm{a} \mathrm{n} \mathrm{d} \mathrm{e} \mathrm{s} \mathrm{t} \mathrm{i} \mathrm{m} \mathrm{a} \mathrm{t} \mathrm{e} \mathrm{s.}$ http://www.usda.gov/oce/ commodity/wasde/latest.pdf.

Vogt, H. 1966. The use of tapioca meal in poultry rations. World Poult. Sci. J. 22:113-126.

Received: $14^{\text {th }}$ October, 2020 Accepted: $5^{\text {th }}$ February, 2021 